\title{
GIS-BASED SPATIAL ANALYSIS OF SINKHOLES IN CEBU CITY, PHILIPPINES: INSIGHTS ON SINKHOLE GENESIS AND DEVELOPMENT
}

\section{Regina Martha G. Lumongsod}

National Institute of Geological Sciences, College of Science, University of the Philippines Diliman

P. Velasquez cor. C.P. Garcia Avenue, Diliman, Quezon City, National Capital Region, 1101, Philippines, rglumong-

sod@up.edu.ph

\section{Noelynna T. Ramos}

National Institute of Geological Sciences, College of Science, University of the Philippines Diliman

P. Velasquez Street cor. C.P. Garcia Avenue, Diliman, Quezon City, National Capital Region, 1101, Philippines, noelynna.ramos@up.edu.ph

\section{Roseanne V. Ramos}

Department of Geodetic Engineering, College of Engineering, University of the Philippines Diliman Melchor Hall, Roces Street cor. Osmeña Avenue, Diliman, Quezon City, National Capital Region, 1101, Philippines, rvramos@up.edu.ph

\begin{abstract}
In 2017, at least 770 sinkholes were reported to occur in Cebu City, a populated town in the Philippines dominantly underlain by karstic formations. In this study, the genesis and development of these sinkholes were related to various geomorphologic, geologic, and hydrologic factors in order to determine their influence on sinkhole distribution in the area using GIS-based spatial analyses. Results show that the sinkhole frequency varies with respect to the relative age of the underlying karstic formation, slope, and elevation. Most sinkholes occur on younger bedrock, low slope, and low elevation areas. However, sinkholes that occur on younger bedrock are significantly smaller in area than those in older bedrock; in terms of total area, the sum of the areas of sinkholes are greater on relatively older bedrock. Other factors found to influence sinkhole occurrence were lineaments and streams. GIS-based analyses of sinkholes such as those presented in this study are useful for sinkhole susceptibility prediction and disaster risk reduction management efforts of communities.
\end{abstract}

\section{Introduction}

In recent years, sinkhole studies have transitioned from manual field techniques into computerized, automated methods (Antonic' et al., 2001; Doctor and Young, 2013; Miao et al., 2013). Most methods utilize geographic in- formation systems (GIS) software in processing satellite imagery and digital elevation models (DEM) from Light Detection and Ranging (LiDAR) and Interferometric Synthetic Aperture Radar (IfSAR) data. However, previous studies have recognized that these automated methods are highly localized and variable between different environments (Doctor and Young, 2013; Green, 2015). Most authors concentrate on small-scale study areas (i.e., less than $100 \mathrm{~km}^{2}$ ) and use high-resolution images and DEMs to monitor and detect sinkholes (Miao et al., 2013; Intrieri et al., 2015). Consequently, these areas typically have little to no variation in terms of lithology, allowing the analysis of sinkholes belonging only under a single formation. Studies on sinkhole genesis and development, much like karstification studies in general, commonly look at geological, geomorphological, and hydrological factors and their relative influence on the occurrence and distribution of sinkholes in a specific area (Delle Rose, et al., 2004; Del Prete et al., 2010; Farrant and Cooper, 2008). Geostatistical methods have been employed to enable qualitative correlation of these factors with sinkhole occurrence and clustering (Ciotoli et al., 2016; Cahalan and Milewski; 2018).

Since this is the case, studies on sinkhole genesis have been dependent on local factors and are difficult to generalize (Doctor and Young, 2013). For the Philippines, studies on sinkholes are limited and most data are only 
found on news articles and mandated agency reports. Thus, sinkhole studies specific for the Philippines are usually incoherent due to lack of local study sources.

This study aims to explore the relationship between sinkhole morphometry and the different rock formations on which they occur. Morphological measurements were correlated with various geological and geomorphological factors (e.g., lithology, slope, proximity to faults, etc.) in order to evaluate the likely occurrence of sinkholes in the area. Results of this study will contribute to local efforts on land use planning and risk reduction efforts. Findings from this study will also aid in understanding sinkhole formation and development in tropical countries like the Philippines.

\section{Study Area}

Cebu Island is dominantly underlain by sedimentary formations (Figure 1), most of which are limestone-bearing (Aurelio and Peña, 2010; Porth et al., 1989). Limestone is a highly soluble carbonate rock, and the dissolution of limestone bedrock results in the formation of karst. Karst terrain is characterized by distinct surface and subsurface features, including sinkholes, caves, and subterranean streams (Monroe, 1970).

At least 770 sinkholes were reported to occur in Cebu City according to a report by the Mines and Geosciences Bureau Region 7 (Leyson, 2017; Mejia and Bunachita, 2017). These sinkholes occur in four formational units that generally comprise Cebu City's geology: Cebu Formation, Malubog Formation, Carcar Formation, and Quaternary Alluvium (BMG, 1983). Hence, sinkhole occurrence poses a major threat to Cebu City's residents.

Cebu Formation is the oldest limestone-bearing formation in Cebu City with an age of Late Oligocene (Corby et al., 1951). It is composed of two members: a lower coal measure (previously Cebu Coal Measures) and an upper orbitoid-rich Ilag Limestone (Aurelio and Peña, 2010). Conformably overlying the Cebu Formation is the Malubog Formation, dated Late Oligocene to Early Miocene based on fossil studies by Porth and others (1989) and Foronda (1994). It is characterized by interbedded clastic rocks and limestone with occasional coal stringers (Aurelio and Peña, 2010). The youngest formation of the entire Cebu Island is Carcar Formation, with an age of Late Pliocene to Pleistocene (Müller et al., 1989;

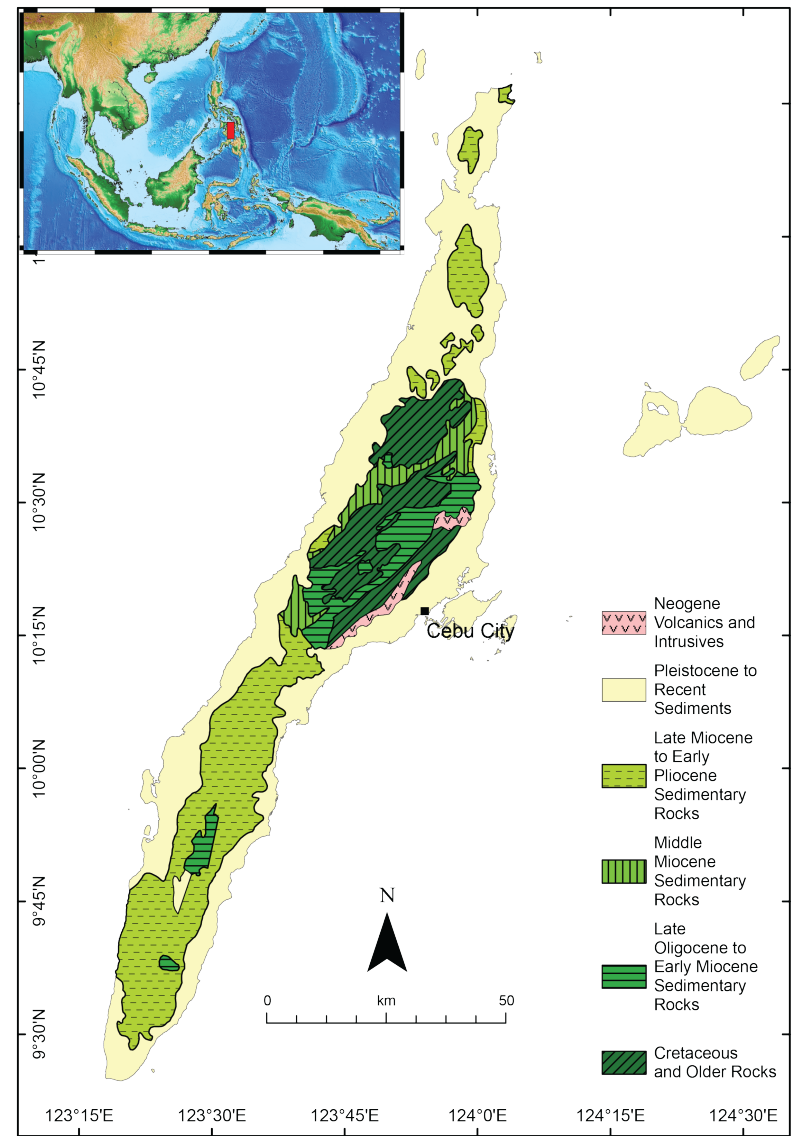

Figure 1. General lithology of Cebu Island (modified from Porth et al., 1989; inset: red box showing the location of Cebu Island). Cebu Island is predominantly underlain by sedimentary formations. The map also shows the location of Cebu City (Fig. 2), which is mostly underlain by Pleistocene to Recent sediments.

Porth et al., 1989). Carcar Formation fringes the entire island and is characterized by coralline, porous, dolomitic limestone (Aurelio and Peña, 2010). These three formations are overlain by recent sediments (Quaternary Alluvium).

\section{Methodology}

A GIS database of sinkholes was built stemming from the ground-validated sinkholes reported by the Mines and Geosciences Bureau (Figure 2). Sinkholes were treated in this study both as points (centroids, used for frequency and proximity analyses) and as polygons (for morphometric analyses). These were then spatially analyzed based on the following geological and geomorpho- 
logical factors: formational unit, lineaments, streams, elevation, and slope (Green, 2015).

Five-meter resolution IFSAR was used to automatically delineate the streams in the area using hydrology tools. Terrain analysis was used to analyze the topography of the area from the IFSAR DEM to obtain slope gradient and elevation maps. Geologic maps from the Mines and Geosciences Bureau (BMG, 1983) were digitized to provide information on the lithology of the area as well as the extent of the different karstic formations. Lineaments were obtained from previous works on the Central Cebu Fault System (Mendoza et al., 2019).

\section{Sinkhole Polygons}

Sinkhole polygons were measured for the following geometric properties following the methods of Doctor and Young (2013) and Miao and others (2013): area, com-

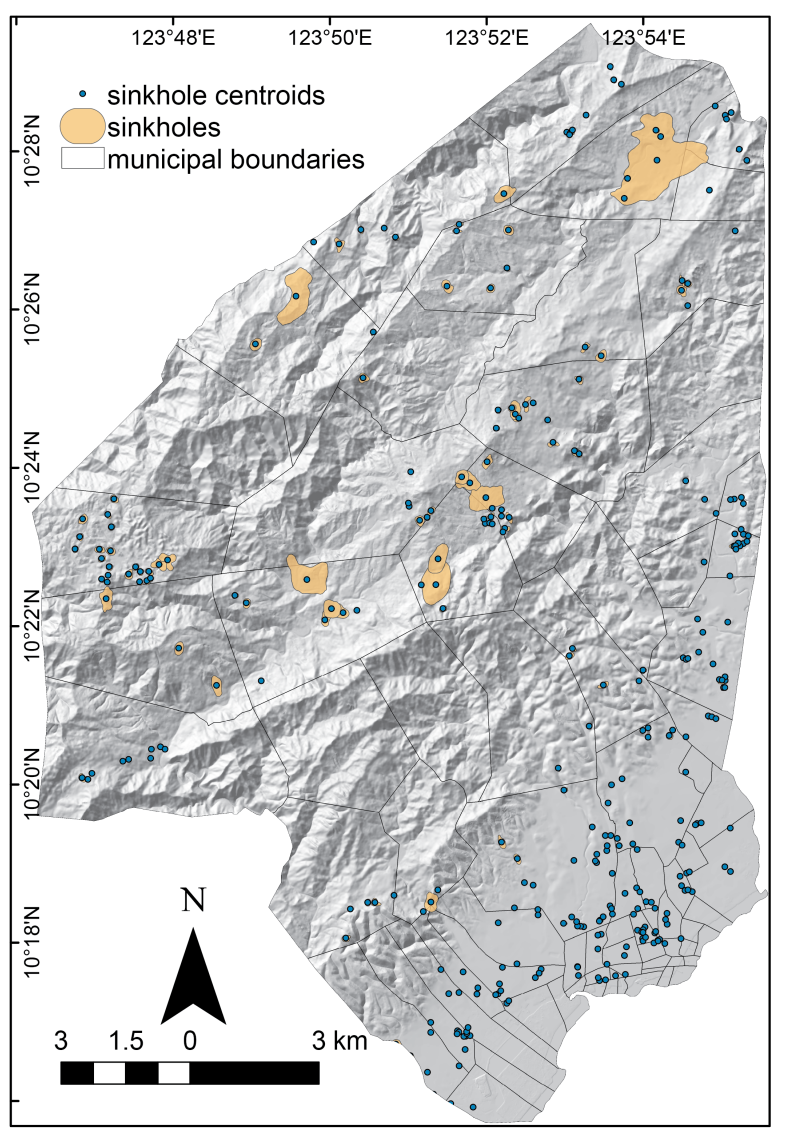

Figure 2. Hillshade map of Cebu City. Sinkholes were treated both as polygons and points (centroids) in this study. pactness, eccentricity, index of circularity, and orientation (Table 1), generated automatically based on Field Calculator and Minimum Bounding Geometry. These values were then compared based on the following layers: formational units, slope, and elevation. The total area of sinkholes, percent sinkholes, and sinkhole density (White, 1988) per formation were also plotted.

\section{Sinkhole Centroids}

The centroid of each sinkhole polygon was obtained and used for point data analyses such as frequency and proximity. Each sinkhole was treated as a centroid under the assumption that sinkhole development progresses from a point source due to focused dissolution (Ford and Williams, 2007). Attributes of the centroids included fields from the original sinkhole polygons, as well as the elevation and slope gradient obtained using Extract tool. The proximity of each centroid with respect to both streams and lineaments were also investigated using the Near tool and the measured distances were added as new, separate attributes. Sinkhole frequency was plotted against the following factors: formational unit, orientation (Chen et al., 2018), elevation, slope gradient, and distances from the nearest stream and lineament (Faivre and Pahernik, 2007).

\begin{tabular}{|l|l|}
\hline Feature & Formula/Definition \\
\hline Area & $\begin{array}{l}\text {, where is the number of pixels } \\
\text { within the boundary }\end{array}$ \\
\hline Compactness & \\
\hline Eccentricity & $\begin{array}{l}\text {, where is the semi major axis, and } \\
\text { is the semi minor axis }\end{array}$ \\
\hline $\begin{array}{l}\text { Circularity } \\
\text { index }\end{array}$ & $\begin{array}{l}\text {, where is the observed perimeter, } \\
\text { and is the expected perimeter () }\end{array}$ \\
\hline $\begin{array}{l}\text { Sinkhole } \\
\text { density }\end{array}$ & \\
\hline $\begin{array}{l}\text { Percent } \\
\text { sinkhole }\end{array}$ & \\
\hline
\end{tabular}

Table 1. Sinkhole features calculated for the morphometric analyses in this study (White, 1988; Doctor \& Young, 2013; Miao et al., 2013). 


\section{Results}

\section{Sinkhole geometry}

The area of sinkholes in Cebu City vary greatly, ranging from $80 \mathrm{~m}^{2}$ to $2.5 \mathrm{~km}^{2}$. The largest total area sinkholes in the area occur in the Malubog Formation (2.5 $\mathrm{km}^{2}$ ), while the smallest sinkholes in the area occur in the Quaternary Alluvium $\left(80 \mathrm{~m}^{2}\right)$ (Figure 3A). In terms of minimum and maximum values, there is a seemingly increasing trend in area from the youngest to the oldest formational units.

Three measures of circularity were used in this study: eccentricity, compactness, and circularity index. These indices all refer to how close the shape of the sinkholes is to that of a perfect circle. However, each index uses different parameters (Table 1) and are normalized differently. In terms of eccentricity (Figure 3B), most sinkholes in Cebu City deviate from the eccentricity value of a perfect circle, which is zero. There seems to be an increase in eccentricity within the older formations, with the maximum eccentricity belonging to sinkholes from
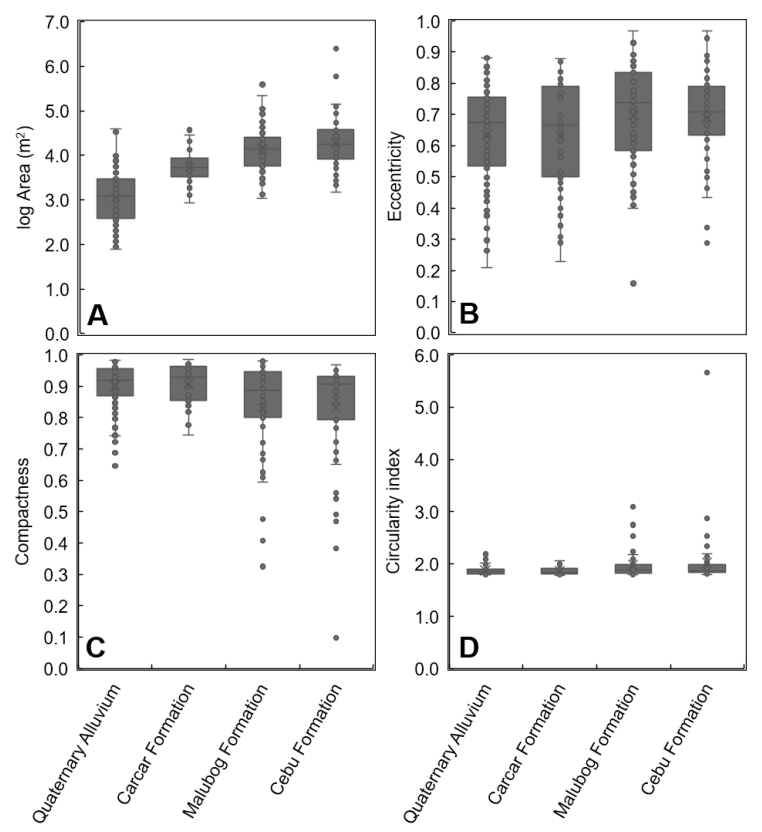

Figure 3. Plots of area (A), eccentricity (B), compactness (C), and circularity index (D) versus the different formational units arranged based on increasing relative age. All four parameters show an increasing area and decreasing circularity with increasing relative age of bedrock. the Malubog Formation and Cebu Formation (0.968 and 0.967 , respectively). The deviation of the sinkholes from the dimensions of a perfect circle is reiterated by the compactness, where increasing values (approaching 1) means more circularity. The plot of compactness (Figure 3C) values for the sinkhole show a decreasing trend towards increasing relative age, with the lowest compactness value (0.098) belonging to a sinkhole in the Cebu Formation. This is again supported by the values for circularity index (Figure 3D), wherein the highest value (5.66) belongs to a sinkhole in the Cebu Formation, the oldest among the four.

\section{Streams and lineaments}

Multiple streams and selected lineaments can be found within the vicinity of Cebu City (Figure 4A). Most of the sinkholes occur within less than $200 \mathrm{~m}$ from a stream (Figure 4B). After $100 \mathrm{~m}$, the frequency of sinkholes declines with increasing distance from any nearby stream. The influence of lineaments was also explored by plotting frequency versus distance from the nearest lineament (Figure 4C) and getting the general direction of elongation (orientation) of the sinkholes (Figure 4D). The distribution of sinkholes with increasing nearest lineament distance does not seem to have any correlation, with the histogram showing four peaks in the following distances: $500 \mathrm{~m}, 1500 \mathrm{~m}, 3000 \mathrm{~m}$, and $4000 \mathrm{~m}$. It can be noted, however, that most sinkholes occur less than 500 $\mathrm{m}$ away from the nearest lineament. Since there seems to be no correlation with frequency and distance from lineaments, the orientation was then looked at. Most sinkholes trend west and northeast, following the trend of most streams and lineaments, respectively.

\section{Slope and elevation}

Sinkhole frequency was also geographically compared with the changes in the degree of slope (Figure 5A) and elevation (Figure 5B) of the terrain. Most sinkholes occur in slopes less than $5^{\circ}$ (Figure 5C). A decrease in sinkhole frequency can also be seen with increasing slope steepness. In contrast, no general trend can be established when elevation is compared with frequency (Figure 5D). It is worth noting, however, that most of the sinkholes in the area are found at elevations of 50 masl or less. These pertain to the multiple sinkhole centroids that are found near the coast. 

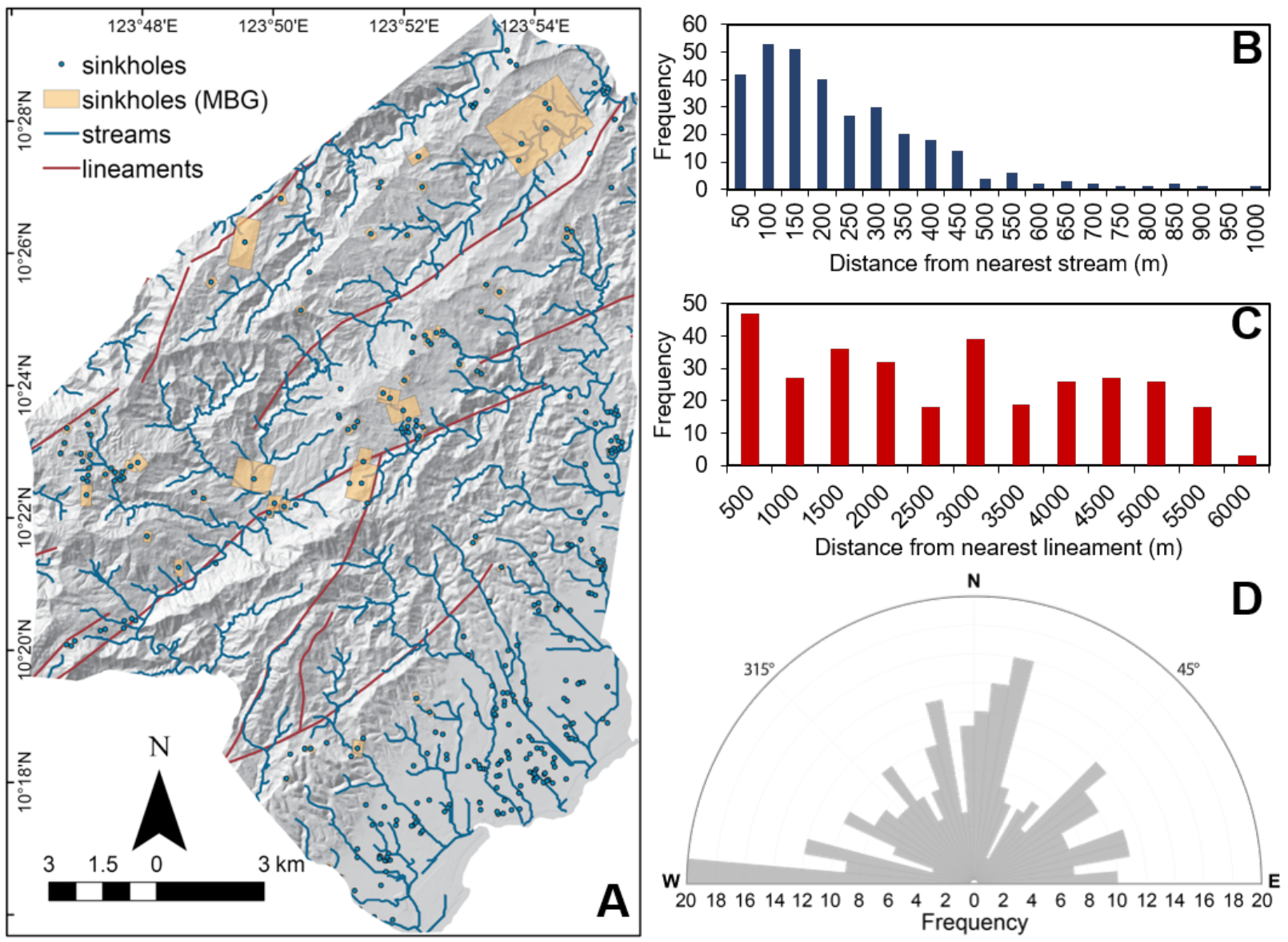

Figure 4. (A) Simple geomorphological map of Cebu City showing streams, lineaments, and sinkholes. Most sinkholes occur near streams (B) and lineaments (C). This influence can also be seen by their similar trends: west for streams and northeast for lineaments (D).

\section{Formational units and relative age}

Sinkholes in Cebu City plot only on limestone-bearing/ karst formations (Figure 6A). In terms of frequency, a general decreasing trend with increasing relative age can be observed, with most sinkholes occurring within the Quaternary Alluvium (133 of 319 ground-validated sinkholes) (Figure 6B). It can also be observed that because more than $1 / 3$ of sinkholes occur within the most recent sediments, percent sinkhole (Figure 6C) and sinkhole density (Figure 6D) is also highest in the Quaternary Alluvium. If these anomalously high values are separated, however, it can be noted that there is a general increasing trend in terms of both percent sinkhole and sinkhole density with increasing relative age of formational unit.

\section{Discussion}

Results show that sinkhole morphometry and distribution are affected by the following geological and geomorphological factors: relative age of bedrock, slope, elevation, and presence of streams and lineaments. The relative age of limestone-bearing bedrock is correlated to affect the shape of the sinkhole as well as its frequency. Generally, the shape of the sinkholes deviates in an increasing manner from that of a perfect circle with increasing relative age of the underlying karst formation (Figure 3). Frequency is also correlated to decrease with increasing relative age, but percent sinkhole and sinkhole density tends to increase given the same trend (Figure 6B-D). A possible explanation for these trends is the 

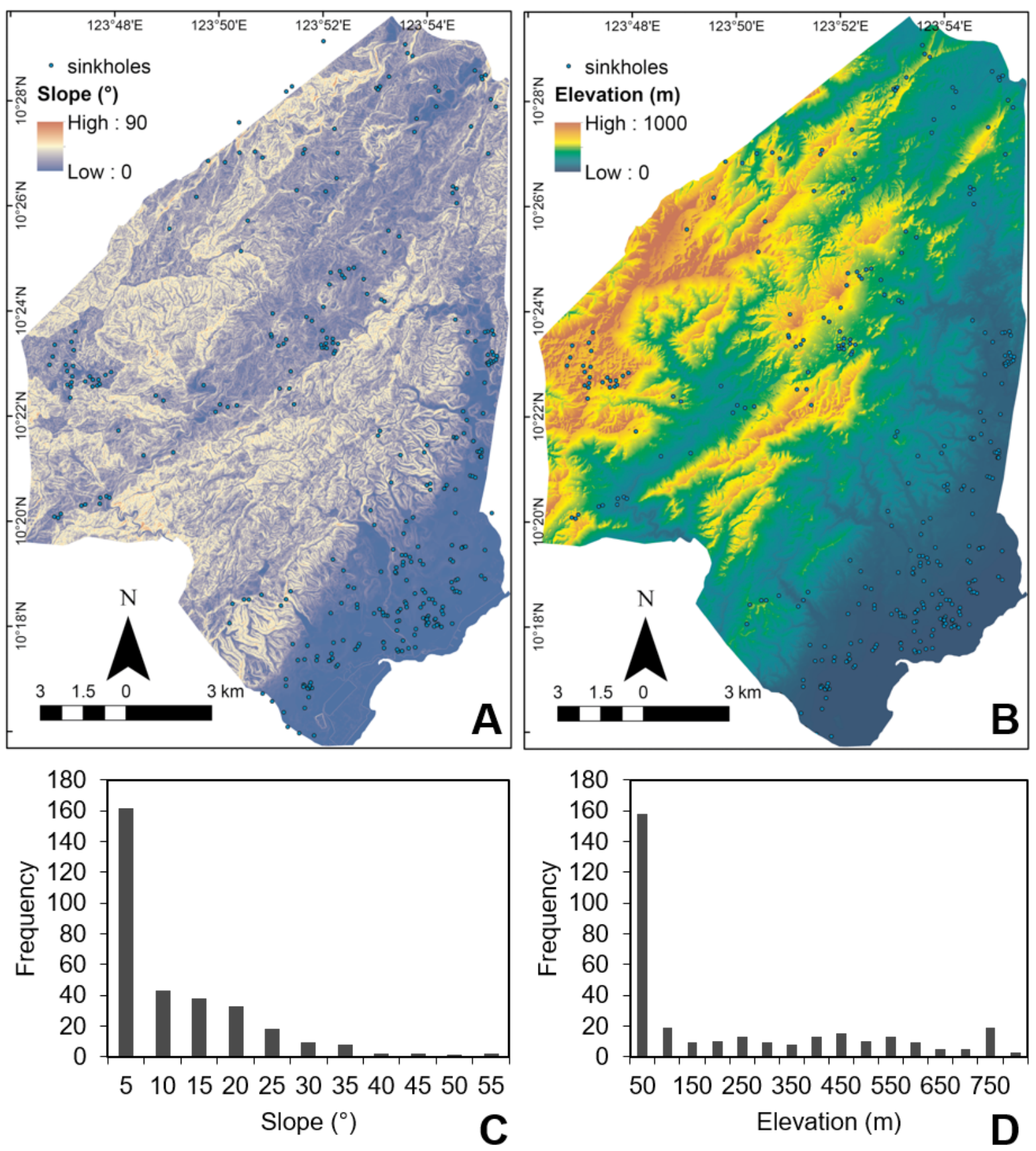

Figure 5. Slope (A) and elevation (B) maps of Cebu City showing sinkhole centroids. A decreasing trend in frequency with increasing slope steepness can clearly be observed (C). No general trend is established when it comes to elevation, but it can be noted that most sinkholes are found below 50 masl.

coalescence of sinkholes. As the bedrock becomes more karstified with time, the sinkholes tend to grow larger (Figure 3A) and eventually coalesces. This coalescence increases the sinkhole's elliptical shape (Figure 3B-D) and area. Because of this, sinkhole count becomes much less, since two coalesced sinkholes will then be counted as one (Figure 6B), but there will also be an accompanying increase in sinkhole area relative to the total area of the karst bedrock (Figure 6C-D). The concentration of more circular sinkholes in the more recent deposits can 

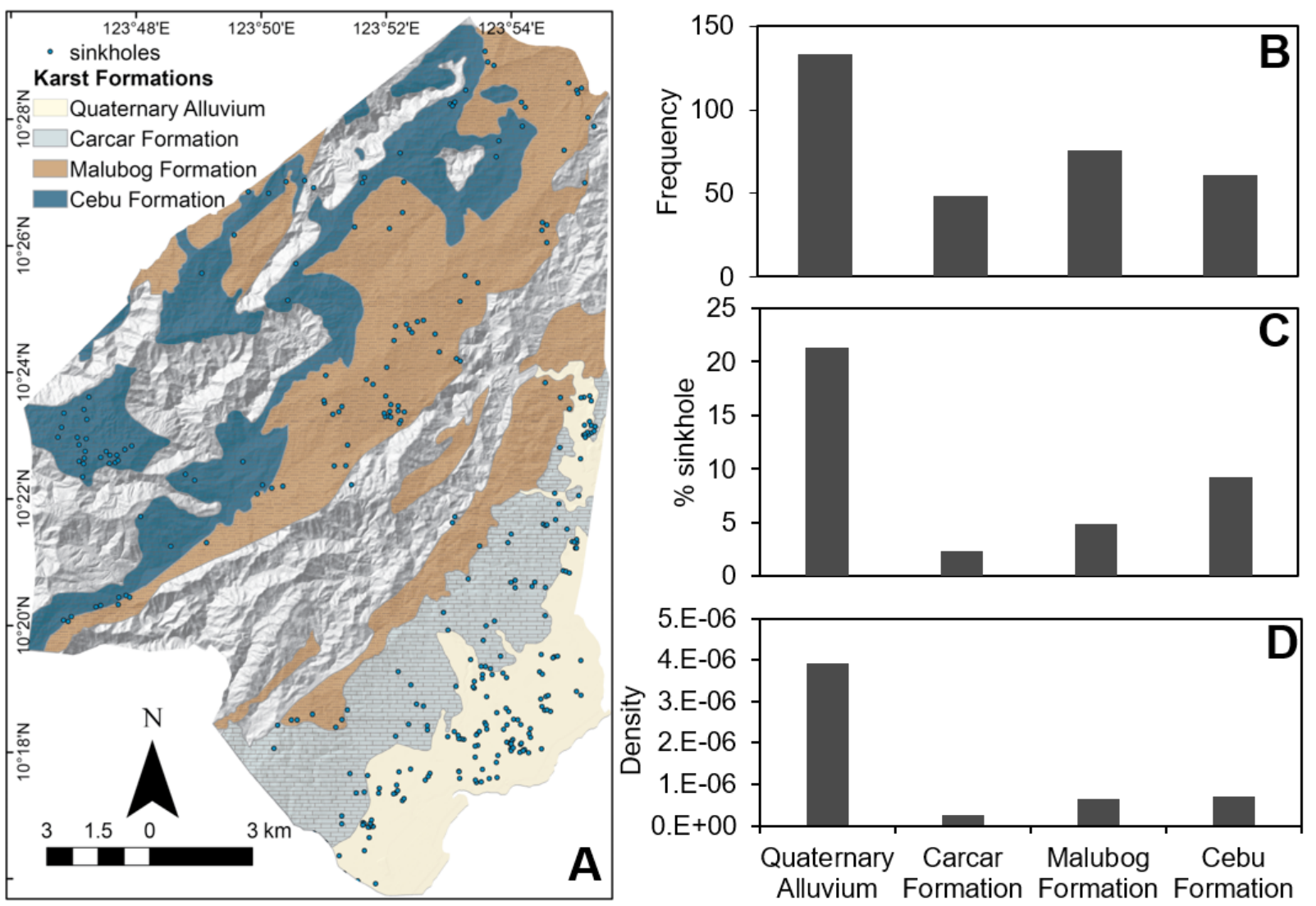

Figure 6. Map showing the distribution of karst formations in Cebu City (modified from MGB, 1983). A general decreasing trend in frequency with increasing relative age of limestone-bearing bedrock can clearly be observed (B). Since most of the sinkholes occur on Quaternary Alluvium, the percent sinkhole and sinkhole density that is yielded is anomalously high (D). Separating the values from this deposit leaves a trend of increasing percent sinkhole and sinkhole density with increasing relative age of formation.

also be due to their smaller area and diameter, which allows their values to approach near circular dimensions.

The shape, orientation, and frequency of sinkholes were also observed to vary depending on the nearest linear feature (Figure 4). Most sinkholes occur near streams (Figure 4B). This is because most dissolution occurs near areas with water, such as streams (Ford and Williams, 2007). The direction of elongation of sinkholes depends on the orientation of the nearest stream or lineament. This explains the two dominant trends in the strike of sinkhole orientation: west, which follows majority of the orientation of streams, and northeast, which is the general trend of the lineaments and Cebu Island itself.

The terrain also influences sinkhole occurrence, and this was observed by comparing the frequency with changes in slope and elevation across the study area. Most sinkholes occur on flat to gentle slopes and low elevation (Figure 5). This can be explained by water ponding, wherein the water becomes more concentrated and resides in a particular area due to a generally flat slope, allowing longer and more concentrated dissolution of the underlying bedrock. The concentration of sinkholes in lower elevations can also be explained by slope, since the areas near the coast tend to be flatter than towards the west of Cebu City, where the highlands can already be seen.

\section{Conclusion}

This study related the morphometry and frequency of sinkholes with the geological and geomorphological factors present in Cebu City using GIS-based morphomet- 
ric and terrain analyses. The results of the morphometric analyses and correlation show that there are at least four factors that significantly affect the shape and occurrence of sinkholes in Cebu City: relative age of underlying karstic bedrock, presence of streams and lineaments, elevation, and slope. Most sinkholes in Cebu City occur in flat to gentle slopes and low elevation. A possible explanation for this is the effect of slopes in surface runoff movement. Gentler slopes allow for the ponding of water, which positively feeds the dissolution of the underlying karst bedrock. This is further justified by the high number of sinkholes that occur near streams, which may have allowed water to reach and dissolve the bedrock sooner. Moreover, the direction of elongation of sinkholes are affected by the nearest stream or lineament, as evidenced by the dominantly west and northeast trends of sinkholes which is consistent with the general trend of streams and lineaments in the area, respectively.

The relative age of the underlying bedrock affects the morphometry and occurrence of sinkholes. It was observed that with increasing relative age, there is also an increase in sinkhole area, percent sinkhole, and sinkhole density, and decrease in sinkhole frequency. This may be due to sinkhole coalescence, a phenomenon that occurs with sinkhole development, which decreases the total number of sinkholes but increases its area and ellipticity as the karst bedrock becomes older and more karstified.

Deviations in the values yielded in this study can be due to the treatment of sinkholes as centroids. It is recommended in future studies for the distal points along the perimeter of the sinkholes to be used in proximity analyses to be able to depict not only sinkhole genesis from a point source, but also sinkhole development which involves coalescence. Moreover, it will also be useful for sinkhole depth to be used in morphometric analyses, so the three-dimensional shape can be studied, and models can better reflect real-life scenarios.

To improve and further this study, it is also recommended to explore other factors affecting sinkhole formation such as the characteristics of the superficial deposit, as well as detailed studies on the bedrock (i.e., limestone). Overall, this study serves as a guide in preliminarily delineating areas prone to sinkhole formation in Cebu as well as similar areas.

\section{References}

Antonic' O, Hatic D, Pernar R. 2001. DEM-based depth in sink as an environmental estimator. Ecological Modelling 138: 247-254.

Aurelio MA, Peña RE. 2010. Geology of the Philippines. 2nd ed. Manila: Mines and Geosciences Bureau. 532 p.

Bureau of Mines and Geo-sciences. 1983. Geological Map of Buanoy Quadrangle. 1:50,000. Manila: Philippine Bureau of Mines and Geo-sciences.

Cahalan MD, Milewski AM. 2018. Sinkhole formation mechanisms and geostatistical-based prediction analysis in a mantled karst terrain. Catena 165 : 333-344.

Chen H, Oguchi T, Wu P. 2018. Morphometric analysis of sinkholes using a semi-automatic approach in Zhijin County, China. Arabian Journal of Geosciences 11: 412-427.

Ciotoli G, Di Loreto E, Finoia MG, Liperi L, Meloni F, Nisio S, Sericola A. 2016. Sinkhole susceptibility, Lazio Region, central Italy. Journal of Maps 12 (2): 287-294.

Corby GW, Kleinpell RM, Popenoe WP, Merchant R, William H, Teves J, Grey R, Daleon B, Mamaclay F, Villongco A, Herrera M, Guillen J, Hollister JS, Johnson HN, Billings MH, Fryxell EM, Taylor EF, Nelson CN, Birch DC, Reed RW, Marquez. 1951. Geology and oil possibilities of the Philippines. Bureau of Mines Technical Bullettin 21.365 p.

Del Prete S, Di Crescenzo G, Santangelo N, Santo A. 2010. Collapse sinkholes in Campania (southern Italy): predisposing factors, genetic hypothesis and susceptibility. Zeitschrift für Geomorphologie 54 (2): 259-284.

Delle Rose M, Federico A, Parise M. 2004. Sinkhole genesis and evolution in Apulia, and their interrelations with the anthropogenic environment. Natural Hazards and Earth System Sciences 4: 747-755.

Doctor KZ, Doctor DH, Kronenfeld B, Wong DWS, Brezinski DK. 2008. Predicting sinkhole susceptibility in Frederick Valley, Maryland, using geographically weighted regression. In: Yuhr LB, Alexander ECJ, Beck BF, editors. 
Sinkholes and the Engineering and Environmental Impacts of Karst. Proceedings of the Eleventh Multidisciplinary Conference; 2004; Geotechnical Special Publication no. 183, American Society of Civil Engineers. p. 243-256.

Doctor DH, Young JA. 2013. An evaluation of automated GIS tools for delineating karst sinkholes and closed depressions from 1-meter LIDAR-derived digital elevation data. In: Land L, Doctor DH, Stephenson JB. Proceedings of the 13th Multidisciplinary Conference on Sinkholes and the Engineering and Environments Impacts of Karst; 2013 May 6-10; Carlsbad, New Mexico: NCKRI Symposium 2. Carlsbad (NM): National Cave and Karst Research Institute.

Faivre S, Pahernik M. 2007. Structural influences on the spatial distribution of solines, Island of Brač, Croatia. Zeitschrift für Geomorphologie 51 (4): 487-503.

Farrant AR, Cooper AH. 2008. Karst geohazards in the UK: the use of digital data for hazard management. Quaternary Journal of Engineering Geology and Hydrogeology 41: 339-356.

Ford DC, Williams PD. 2007. Karst Hydrogeology and Geomorphology. 1st ed. England: John Wiley \& Sons. 562 p.

Foronda VJ. 1994. Sequence stratigraphy of an Oligocene-Miocene mixed siliciclastic-carbonate system, Visayan Basin, central Cebu, Philippines [doctoral thesis]. Germany: Rheinischen Friedrich-Wilhelms-Universität Bonn. 152 p.

Green TB. 2015. Down the rabbit hole: Identifying physical causes of sinkhole formation in the UK. In: Doctor DH, Land L, Stephenson JB. Proceedings of the 14th Multidisciplinary Conference on Sinkholes and the Engineering and Environments Impacts of Karst; 2015 Oct. 4-9; Rochester, Minnesota: NCKRI Symposium 5. Carlsbad (NM): National Cave and Karst Research Institute.

Intrieri E, Gigli G, Nocentini M, Lombardi L, Mugnai F, Fidolini F, Casagli N. 2015. Sinkhole monitoring and early warning: An experimental and successful GB-InSAR application. Geomorphology 241: 303-314.
Leyson OO. 2017 July 7. Cebu City littered with 770 sinkholes. The Freeman. Available from: https:/www.philstar.com/the-freeman/cebunews/2017/07/07/1717584/cebu-city-littered-770sinkholes.

Mejia IG, Bunachita JSS. 2017 July 7. Cebu City has 770 sinkholes. Cebu Daily News. Available from: https://cebudailynews.inquirer.net/138752/cebucity-770-sinkholes

Mendoza RBC, Ramos NT, Dimalanta CB. 2019. Fault geometry and seismic hazard of the Central Cebu Fault, Philippines. Abstracts of the 16th Annual Meeting of the Asia Oceania Geosciences Society. 2019 Jul. 28-Aug. 2; Singapore.

Miao X, Qiu X, Wu SS, Luo J, Gouzle DR, X, H. 2013. Developing efficient procedures for automated sinkhole extraction from LIDAR DEMs. Photogrammetric Engineering and Remote Sensing: 1-10.

Monroe, WH. 1970. A Glossary of Karst Terminology. North Capitol (WA): United States Government Printing Office. 25 p.

Müller C, von Daniels CH, Cepek P, Gramann F, Bausa GJG, De Leon MM. 1989. Biostratigraphy and paleoenvironmental studies in the Tertiary of the Visayan Basin, Philippines. Geologisches Jahrbuck 70: 89-145.

Müller C, von Daniels CH, Cepek P, Gramann F, Bausa GJG, De Leon MM. 1989. Biostratigraphy and paleoenvironmental studies in the Tertiary of the Visayan Basin, Philippines. Geologisches Jahrbuck 70: 89-145.

Porth H, Müller C, von Daniels CH. 1989. The Sedimentary Formations of the Visayan Basin, Philippines. Geologisches Jahrbuck 70: 29-87.

White W. 1988. Geomorphology and hydrology of karst terrains. New York (NY): Oxford University Press. 508 p. 